\title{
EVIDENCE-BASED NON-PHARMACOLOGICAL TREATMENT OF OSTEOARTHRITIS
}

\author{
NEFARMAKOLOŠKO LIJEČENJE OSTEOARTRITISA \\ UTEMELJENO NA DOKAZIMA
}

\author{
Ivan Vlak ${ }^{1}$, Tonko Vlak ${ }^{1,2}$ \\ ${ }^{1}$ Institute of Physical Medicine, Rehabilitation and Rheumatology, Clinical Hospital Center Split, Split, Croatia \\ / Zavod za fizikalnu medicinu i rehabilitaciju s reumatologijom, Klinički bolnički centar Split, Split, Hrvatska \\ ${ }^{2}$ Department of Rehabilitation and Physical Medicine, School of Medicine, University of Split, Split, Croatia \\ / Katedra za rehabilitacijsku i fizikalnu medicinu, Medicinski fakultet Split, Sveučilište u Splitu, Split, Hrvatska
}

\author{
Corresponding author / Adresa autora za dopisivanje: \\ Prof. dr. sc. Tonko Vlak, prim. dr. med. \\ Institute of Physical Medicine, Rehabilitation and Rheumatology \\ / Zavod za fizikalnu medicinu i rehabilitaciju s reumatologijom \\ Clinical Hospital Centre Split / Klinički bolnički centar Split \\ Šoltanska 1, 21000 Split \\ Croatia / Hrvatska \\ Phone / tel.: +38521557563 \\ E-mail / e-pošta: tonkovlak@gmail.com \\ Received / Primljeno: September 25, 2020 / 25. rujna 2020. \\ Accepted / Prihvaćeno: November 26, 2020 / 26. studenoga 2020.
}

\section{ABSTRACT}

Osteoarthritis (OA) is the most common rheumatic joint disease, but also a disease that affects the entire joint and all structures surrounding the joint (periarticular structures). Literature dealing with this topic most commonly includes results related to the treatment of knee osteoarthritis (OA), while other localisations of degenerative changes of the joints are not researched in such a detailed way. In addition to that, these degenerative changes exhibit less evidence strength, so the same will be used in this review. According to the latest 2019 ESCEO guidelines for the treatment of OA, non-pharmacological treatment (NPT) has an important role in OA treatment and it is a part of all OA treatment algorithms, and it has to be a part of evidence-based medicine (EBM).

With technological progress in rehabilitation medicine, new solutions have appeared, as well as new forms of NPT aimed at helping patients, relieving pain, increasing the patients' functional ability and improving their quality of life. Due to this, in this literature review, which was accessed through the Cochrane library, PEDro database and PubMed search, we mostly found discussions about new technologies in OA treatment.

During that search, we can easily conclude that results of many systematic reviews and meta-analyses about the use of conventional methods of physical therapy did not change much compared to the methods used 10 years ago. When it comes to all of these methods, medical exercise is considered to be the most effective one, with the highest evidence strength. Nowadays, as opposed to literature sources in the past, in most literature we are able to find a significantly more accurate and precise definition of the term "physical activity". It is defined as an activity performed during an individual's stay at their workplace, during transport, while doing one's chores or housework, and during leisure time. We believe that the newest, modern technologies in rehabilitation medicine, such as the following ones: high-intensity laser therapy (HILT), extracorporeal shock wave therapy (ESWT), radio frequency (RF) and electromagnetic therapy super inductive system (SIS), present the biggest challenge in the NPT of OA today. These treatment methods, according to the available EBM data, have shown outstanding efficiency in the treatment of OA by reducing the patients' pain, improving patients' functional ability as well as their quality of life, with minimal adverse effects. Today, the general opinion is that we should give advantage to modern technologies in combination with already well-known and defined medical exercises with implementing preventive activities.

Key Words: Osteoarthritis, knee - rehabilitation, therapy; Exercise therapy; Physical therapy modalities; Laser therapy; Extracorporeal shockwave therapy; Radiofrequency therapy; Pulsed electromagnetic field therapy; Pain; Treatment outcome; Evidence-based medicine 


\section{SAŽETAK}

Osteoartritis $(\mathrm{OA})$ najčešća je reumatska bolest zgloba i svih okolozglobnih struktura. U literaturi su najčešće zastupljeni rezultati vezani uz liječenje OA koljena, a ostale lokalizacije degenerativnih promjena zglobnih struktura manje su istraživane. Pritom su i dokazi manje snage pa će tako biti i u ovome preglednom članku. Prema ažuriranim smjernicama ESCEO-a iz 2019. g., bitnu ulogu u liječenju bolesnika s OA ima i nefarmakološko liječenje (NFL) - dio svih algoritama liječenja OA, uz preporuku da mora biti utemeljeno na dokazima (EBM). Tehnološki napredak u rehabilitacijskoj medicini nudi neka nova rješenja, nove oblike NFL-a radi pomoći bolesnicima, uklanjanja boli i povećanja funkcionalnih mogućnosti, čime se poboljšava i kvaliteta života. Zbog toga se u literaturi koja je dostupna pregledom Cochraneove knjižnice, baze PEDro i tražilice PubMed danas najčešće raspravlja o novim tehnologijama u liječenju OA. Primjećujemo da se rezultati brojnih sustavnih pregleda i metaanaliza o primjeni konvencionalne fizikalne terapije nisu bitno promijenili u odnosu prema onima u sličnim analizama i prije 10-ak godina. Najučinkovitijom metodom, uz najkvalitetniju snagu dokaza, smatra se medicinska vježba. No, za razliku otprije, danas u literaturi nalazimo znatno točniju i precizniju definiciju pojma tjelesne aktivnosti: to je aktivnost tijekom boravka na radnome mjestu, za vrijeme transporta, tijekom obavljanja kućanskih poslova i u slobodno vrijeme. Najveći izazov u NFL-u OA danas jesu moderne tehnologije u rehabilitacijskoj medicini, a to su terapije laserom visokog intenziteta (HILT), udarnim valom (ESWT), radiofrekvencijom (RF) i elektromagnetskim poljem visokog intenziteta (SIS). Te metode liječenja, prema dostupnim podatcima EBM-a, pokazale su izrazitu učinkovitost u liječenju OA: reduciranu bol kod ispitanika, poboljšane funkcionalne sposobnosti i kvalitetu života bolesnika. Sve to uz izrazito malo neželjenih događaja. Danas je uvriježeno mišljenje da treba davati prednost modernim tehnologijama, dobro definiranim medicinskim vježbama i provođenju preventivnih aktivnosti.

KLJUČNE RIJEČI: Osteoartritis koljena - liječenje, rehabilitacija; Terapijske vježbe; Fizioterapijske tehnike; Terapija laserom; Izvantjelesna terapija udarnim valom; Radiofrekvencijska terapija; Terapija elektromagnetskim poljem; Bol; Ishod liječenja; Medicina utemeljena na dokazima

\section{INTRODUCTION}

Nowadays, osteoarthritis (OA) has become increasingly perceived as a huge global issue and the most common rheumatic disease $(1,2)$. The socioeconomic and health significance of OA in the overall pathology of the population is continuously increasing, mainly due to a significant increase in two risk factors: an increase in the share of the elderly in the overall population and an increase in the number of obese individuals in the overall population, especially in the younger (working-age) age groups $(3,4)$. There is a significantly positive correlation between the incidence of $\mathrm{OA}$ and both risk factors, which is why this disease will continue to be in the centre of interest of both public health workers as well as rheumatologists and physiatrists for a long time. The disease (OA) is manifested by morphological, biochemical, molecular, and biomechanical changes of cells and intercellular substance in all tissues that make up the diarthrodial joint $(2,4)$. Therefore, we need to be aware of the fact that OA is a disease which affects the entire joint and periarticular structures, not just the articular cartilage as is most commonly thought.

Due to the aforementioned facts, it was necessary to prepare and create certain algorithms, that is, procedures for the prevention, treatment and rehabilitation of patients suffering from the said conditions. So, with this in mind, the professional societies of the Croatian Medical Association, such as the Croatian Society for Rheumatology in 2010 (5) and the Croatian Society of

\section{UVOD}

Osteoartritis (OA) se sve više percipira kao velik globalni problem i najučestalija reumatska bolest današnjice $(1,2)$. Sve je veće i socioekonomsko i zdravstveno značenje $\mathrm{OA}$ u sveukupnoj patologiji pučanstva, a poglavito zbog znatnog povećanja dvaju rizičnih čimbenika: porasta udjela starijih osoba u sveukupnoj populaciji i porasta broja pretilih osoba u sveukupnoj populaciji, poglavito u mlađim (radno aktivnim) dobnim skupinama $(3,4)$. Pritom postoji znatno pozitivna korelacija između pojavnosti OA i obaju rizičnih čimbenika, zbog čega će ova bolest dugo biti u središtu zanimanja i javnozdravstvenih radnika i reumatologa i fizijatara. Bolest (OA) se manifestira morfološkim, biokemijskim, molekularnim i biomehaničkim promjenama stanica i međustanične tvari u svim tkivima koja čine diartrodijalni zglob $(2,4)$. Zato trebamo biti svjesni činjenice da je OA bolest cijeloga zgloba i okolozglobnih struktura, a ne samo zglobne hrskavice kao što se najčešće mislilo.

Zbog prije navedenih činjenica nužno je bilo osmisliti i napraviti algoritme - postupnike prevencije, liječenja i rehabilitacije ovih bolesnika pa su tako stručna društva HLZ-a - Hrvatsko reumatološko društvo 2010. g. (5) i Hrvatsko društvo za fizikalnu i rehabilitacijsku medicinu 2015. g. (6) - takve dokumente donijela na nacionalnoj razini. Pritom je bitno naglasiti činjenicu da se u oba dokumenta velika važnost pridaje nefarmakološkom liječenju (NFL) OA. 
Physical and Rehabilitation Medicine in 2015 (6), have adopted such documents at the national level. It is important to highlight the fact that, in both of these documents, great importance was given to non-pharmacological treatment (NPT) of OA.

NPT includes a number of procedures: education and training, medical gymnastics, weight loss, passive physical therapy, and the use of orthoses $(5,6)$. All of this is in accordance with the latest recommendations of one of the EU umbrella organisations dealing with both social as well as clinical and economic aspects of this disease: the European Society for Clinical and Economic Aspects of Osteoporosis, Osteoarthritis and Musculoskeletal Diseases (ESCEO) (7). The aforementioned organisation notes that all recommendations on the importance and effectiveness of the NPT must be made only on the basis of data obtained using evidencebased medicine (EBM). The ESCEO states that there is an abundance of evidence strength regarding recommendations for the implementation of NPT interventions, with an objective presentation of their overall effectiveness and limitations, but also with an emphasis on the safety of their use in everyday practice (8).

All of the above mentioned facts prompted us to search the latest medical literature on the basis of evidence-based medicine (EBM) and try to find the answer to the following question: what is the level of importance and effectiveness of NPT in terms of OA treatment?

\section{METHODS}

In order to prepare this review article we have performed a search of the following databases that are relevant to the field of rheumatology and rehabilitation medicine: the PEDro database (Physiotherapy Evidence Database), the MEDLINE Library and the Cochrane Library (Cochrane Database of Systematic Reviews). We have also done a search of the references of the relevant papers included in the review article. We have decided to take into consideration only the articles related to the NPT of OA in individuals over the age of 18 , which were published by January 2020 at the latest. The included papers were written in both English and Croatian. With the help of the following keywords: osteoarthritis, non-pharmacological treatment, modalities of physical therapy and rehabilitation, which were harmonised in accordance with MeSH (Medical Subject Headings), and after the exclusion of certain protocols, duplicate articles and articles not related to NPT, we have found a total of 27 relevant articles.

Two researchers have independently selected articles that met the above-mentioned criteria and collected relevant data, and we have noted that most of the data is related to OA of large weight-bearing joints, particularly the knees. There is fewer general data on OA, some data are related to the spine, and the least amount of data collected is the data related to small joints. It is
U NFL se ubrajaju brojni postupci: edukacija, medicinska gimnastika, smanjenje tjelesne težine, pasivna fizikalna terapija, uporaba ortoza $(5,6)$. Sve je to u skladu i s najnovijim preporukama jednog od krovnih europskih tijela koje se bavi i socijalnim i kliničkim te ekonomskim aspektima ove bolesti: Europskog društva za kliničke i ekonomske aspekte osteoporoze, osteoartritisa i mišićno-koštanih bolesti (engl. European Society for Clinical and Economic Aspects of Osteoporosis, Osteoarthritis and Musculoskeletal Diseases ESCEO) (7). Ono pritom napominje da se sve preporuke o važnosti i učinkovitosti NFL-a moraju donositi samo na temelju podataka dobivenih s pomoću medicine utemeljene na dokazima (engl. Evidence-based medicine - EBM). ESCEO navodi da postoji velika snaga dokaza u svezi s preporukama za primjenu intervencija NFL-om, uz objektivnost prikaza svih njihovih učinkovitosti i ograničenosti, ali i naglašenu sigurnost njihove uporabe u svakodnevnoj praksi (8).

Sve prije navedeno potaknulo nas je da na osnovi medicine utemeljene na dokazima (EBM) pretražimo najnoviju medicinsku literaturu i pokušamo odgovoriti na pitanje: koliko je važno i učinkovito NFL u OA.

\section{METODE}

Za izradu ovoga preglednog članka pretražili smo baze podataka koje su relevantne za područje reumatologije i rehabilitacijske medicine: PEDro (engl. Physiotherapy Evidence Database), Medline i Cochraneovu knjižnicu (engl. Cochrane Database of Systematic Reviews). Dodatno smo pretražili referencije relevantnih radova uključenih u pregledni članak. U razmatranje smo uzeli samo članke koji su se odnosili na NFL OA kod osoba starijih od 18 godina, a objavljeni su zaključno do siječnja 2020. g. Uključeni su radovi pisani na engleskom i hrvatskom jeziku. S pomoću ključnih riječi: osteoartritis, nefarmakološko liječenje, modaliteti fizikalne terapije i rehabilitacije, usklađenih prema MeSH-u (engl. Medical Subject Headings), a nakon isključenja protokola, dvostruko ponovljenih članaka i članaka koji se ne odnose na NFL, pronašli smo ukupno 27 relevantnih članaka.

Dvojica su istraživača neovisno odabrala članke koji odgovaraju gore navedenim kriterijima i prikupili relevantne podatke, pri čemu smo uočili da se najveći broj podataka odnosi na OA velikih zglobova, osobito koljena. Manje ima općenitih podataka o $\mathrm{OA}$, ponešto o kralježnici, a najmanje o malim zglobovima. Pritom su, kao kuriozitet, u jednoj analizi nađeni podatci i o OA temporomandibularnih (TM) zglobova (9).

\section{REZULTATI ISTRAŽIVANJA}

Pregled najnovijih preporuka o liječenju OA, objavljenih u medicinskoj literaturi, navodimo s obzirom na 
an interesting fact that data on OA of temporomandibular joints (TMJ) were found in one analysis (9).

\section{RESEARCH RESULTS}

We have provided an overview of the latest OA treatment recommendations published in medical literature, with respect to the type of NPT studied and the efficacy and tolerability monitored on the basis of EBM criteria.

\section{Medical gymnastics / medical exercises / kinesiotherapy / physical activity}

The results of a 2019 study conducted by Natalie Collins et al. showed that 1994 papers were included in the systematic review, including 13 systematic reviews and 36 randomised controlled trials (RCTs). $73 \%$ of these studies have evaluated the effect of NPT of knee OA (36 studies) (10). The other studies have evaluated the effect of NPT of hand OA (6 studies), as well as OA of the hip, hip / knee and generalised OA (2 studies each) and cervical spine OA (1 study). Out of all NPT methods, the method of medical exercises was the most commonly evaluated one in the aforementioned studies (31\%). Finally, the authors have concluded that, in accordance with the current clinical guidelines, medical exercises should be the main procedure in OA rehabilitation, and that future studies should provide conditions for medical exercise programmes to be well defined and in order for them to be more comparable to each other. Therefore, there is still a clear need for research of rehabilitation procedures in OA of the hip, hand, foot, ankle, shoulder, and spine, which were not sufficiently represented in the reviewed studies (10).

Research conducted in 2018 by Ferreira et al. included an overview of 2188 studies, with only 41 of those studies meeting strictly and precisely set criteria. The opinion was based on the results of 35 classified studies, included in accordance with the set, very precise and strict criteria (11). Based on systematic reviews of the literature, the authors have concluded that there is valid evidence that a standard exercise programme can alleviate pain and improve physical function in patients with knee OA (11).

Furthermore, there is moderate or medium strong evidence that acupuncture, hydrotherapy, electroacupuncture, interference currents, kinesiology tape, manual therapy, moxibustion, pulsed electromagnetic field therapy, Tai Chi, ultrasound, yoga and vibration techniques that have been applied to the entire body (more as an adjuvant therapy to the set exercises than as a stand-alone intervention) have proved to be effective with regard to the assessed results (11).

According to the systematic reviews of literature, the quality of evidence for all other interventions was low or it did not exhibit sufficient efficiency which would speak in favour of their application (11). vrstu NFL-a koja je proučavana te učinkovitost i podnošljivost praćene na temelju kriterija EBM-a.

\section{Medicinska gimnastika / medicinske vježbe / kinezioterapija / tjelesna aktivnost}

Rezultati istraživanja Natalie Collins i suradnika iz 2019. g. pokazali su da su u sustavni pregled bila uključena 1994 rada, među kojima je bilo 13 sustavnih pregleda i 36 randomiziranih kontroliranih studija (RCT). Njih 73\% evaluiralo je učinak NFL-a kod OA koljena (36 studija) (10). Ostale su evaluirale učinak NFL-a kod OA šaka (6 studija), kuka, kuka/koljena i generaliziranog OA (po 2 studije za svaki) i OA vratne kralježnice (1 studija). Od svih metoda NFL-a u navedenim je studijama najčešće bila evaluirana metoda medicinskih vježbi (31\%). Na kraju su autori zaključili da bi, u skladu sa sadašnjim kliničkim smjernicama, medicinske vježbe trebale biti glavni postupak pri rehabilitaciji OA, a buduće bi studije trebale osigurati uvjete da programi vježbi budu dobro definirani i međusobno bolje usporedivi. Stoga i dalje postoji jasna potreba za istraživanjima rehabilitacijskih postupaka kod OA kuka, šake, stopala, gležnja, ramena i kralježnice, koji u pregledanim studijama nisu bili dovoljno zastupljeni (10).

Istraživanje Ferreire i suradnika iz 2018. g. uključilo je pregled 2188 studija, pri čemu je samo 41 zadovoljavala strogo i precizno zadane kriterije. Mišljenje je doneseno na temelju rezultata 35 klasificiranih studija, uključenih prema postavljenim, vrlo preciznim i strogim kriterijima (11). Na temelju sustavnih pregleda literature autori su zaključili kako postoji valjani dokaz da standardni program vježbi može ublažiti bol i poboljšati fizičku funkciju kod bolesnika s OA koljena (11).

Nadalje, postoji umjereni ili srednje jaki dokaz da su akupunktura, hidroterapija, elektroakupunktura, interferentne struje, kineziološka vrpca (engl. kinesiology tape), manualna terapija, moksibustija, pulsno elektromagnetsko polje, Tai Chi, ultrazvuk, joga i vibracijske tehnike primijenjene na cijelo tijelo (više kao dodatak vježbama nego kao samostalna intervencija) učinkovite s obzirom na procijenjene rezultate (11).

Prema sustavnim pregledima literature, kvaliteta dokaza za sve ostale intervencije bila je slaba ili nije pokazivala dovoljnu učinkovitost koja bi poduprla njihovu primjenu (11).

Osim toga, uspoređujući pregled svih spomenutih metoda NFL-a, potvrđena je vrijednost zajedničke primjene akupunkture i vježbi. Što se, pak, tiče primjene transkutane električne stimulacije živca (TENS) i lasera niskog intenziteta (LLLT) u procesu smanjenja boli i poboljšanja fizičkih mogućnosti bolesnika, nađeni rezultati bili su različiti (11).

U sustavnom pregledu Ceballos-Laite i suradnika iz 2018. g. ispitivao se učinak, zajednički i pojedinačni, 
In addition to that, by comparing the overviews of all of the aforementioned NPT methods, the value of the joint application of acupuncture and medical exercises was confirmed. With regard to the application of transcutaneous electrical nerve stimulation (TENS) and low-level laser therapy (LLLT) in the process of reducing pain and improving the physical abilities of patients, the results found were different (11).

In the 2018 systematic review prepared by CeballosLaite et al. the joint and individual effects of manual therapy and medical exercises on pain, range of motion and physical abilities of patients suffering from hip OA were researched (12). Finally, the authors have concluded that medical exercises and manual therapy and their combination with patient education and training ensure a good effect on the reduction of pain and improvement of physical function of patients (12). The effect of combination therapy remains unclear due to the inaccurate determination of the effect of individual components on target parameters, so the authors state that further research is required in order to improve knowledge about the effects of these NPT methods on pain and functional capacity of the hip (12).

The significance of physical activity and medical exercises in the treatment of rheumatic diseases, which became increasingly discussed in both medical literature and everyday practice, prompted the European umbrella organisation for rheumatology, European League Against Rheumatism (EULAR), to form a working group that adopted its opinion and published the EULAR guidelines with recommendations for physical activity in patients with inflammatory rheumatic diseases and OA in 2018 (13). According to these guidelines, physical activity includes all forms of movement, i.e. activity in everyday life, including work, recreation and sports activities, and is categorised according to the level of intensity, from low or weak, through moderate to strong or high intensity, with relatively precise variables in their implementation. The recommendations for four types of physical activity are listed below:

a) occupational physical activity,

b) transportation physical activity,

c) housework, home maintenance,

d) leisure-time physical activity.

Nevertheless, the authors conclude that it is necessary to define the type, intensity and frequency of exercise in a better way, and in order to make physical activity and medical exercises as similar as possible to pharmacotherapy for which these parameters are very precisely determined today (13).

In 2019, in an attempt to review Cochrane's cumulative presentation of the benefits of medical exercise in patients with hip OA, Elena Ilieva published the results of an article search from the Cochrane Library that included 21 studies and analysed 12 of them, with a moderate and low quality of evidence (14). The analysed manualne terapije i medicinskih vježbi na bol, opseg pokreta i fizičke sposobnosti u bolesnika s OA kuka (12). Na kraju autori zaključuju da medicinske vježbe i manualna terapija te njihova kombinacija s edukacijom bolesnika osiguravaju dobar učinak na bol i poboljšanje fizičke funkcije (12). Učinak kombinirane terapije ostaje nejasan zbog nepreciznog određivanja utjecaja pojedinih komponenata na ciljne parametre pa autori navode da su potrebna daljnja istraživanja radi unaprjeđenja znanja o učincima spomenutih metoda NFL-a na bol i funkcionalni kapacitet kuka (12).

Značenje tjelesne aktivnosti i medicinskih vježbi u liječenju reumatskih bolesti, kojemu se i u medicinskoj literaturi i u svakodnevnoj praksi počela pridavati sve veća pozornost, potaknulo je i krovno Europsko udruženje reumatologa (EULAR) da formira radnu skupinu koja je o tome donijela svoje mišljenje i 2018. g. objavila EULAR-ove smjernice s preporukama za tjelesnu aktivnost kod bolesnika s upalnim reumatskim bolestima i OA (13). Prema tim smjernicama, tjelesna aktivnost obuhvaća sve pokrete, tj. kretanje u svakodnevnom životu uključujući posao, rekreaciju i sportske aktivnosti, a kategorizirana je s obzirom na razinu intenziteta od niskog odnosno slaboga, preko umjerenoga do snažnog odnosno visokog intenziteta, uz relativno precizne varijable u njihovu provođenju. Navedene su preporuke za četiri vrste tjelesne aktivnosti:

a) tjelesna aktivnost na radnome mjestu (engl. Occupational physical activity)

b) tjelesna aktivnost za vrijeme prijevoza, odnosno putovanja s mjesta na mjesto (engl. Transportation physical activity)

c) tjelesna aktivnost u kući i oko kuće (engl. Housework, home maintenance)

d) tjelesna aktivnost u slobodno vrijeme (engl. Leisure-time physical activity).

Ipak, i ovdje autori u zaključku navode da je potrebno bolje definirati vrstu, intenzitet i učestalost vježbanja, a kako bi tjelesna aktivnost i medicinske vježbe postale što sličnije farmakoterapiji za koju su ti parametri danas vrlo precizno određeni (13).

Želeći se osvrnuti na Cochraneov zbrojni prikaz dobrobiti medicinskih vježbi kod bolesnika s OA kuka, Elena Ilieva objavila je 2019. g. rezultate pretraživanja članaka iz Cochraneove knjižnice koji su uključivali 21 studiju, a analizirano je njih 12, osrednje i slabe kvalitete dokaza (14). Analizirani rezultati dokazali su da bi sudjelovanje u programu vježbi moglo imati važnu ulogu u postupcima NFL-a kod bolesnika s OA, jer ono može znatno poboljšati funkciju zgloba, smanjiti bol i depresiju te povećati samoučinkovitost i društveno funkcioniranje (14). Bolesnike bi pritom trebalo ohrabriti da sudjeluju u programima vježbi osmišljenih prema njihovim osobnim sklonostima, sposobnostima i potrebama, uz savjet i upute zdravstvenih pro- 
results showed that participation in an exercise programme could play an important role in NPT procedures in patients with $\mathrm{OA}$, as it can significantly improve joint function, reduce pain and depression, and increase self-efficacy and social functioning (14). Patients should be encouraged to participate in exercise programmes prepared in accordance with their personal preferences, abilities, and needs, with the advice and guidance of health professionals. OA treatment was evaluated as a complex and multimodal procedure (14).

Thus, based on all of the above mentioned facts, as well as according to all analysed guidelines in the aforementioned publications (EULAR, ESCEO, ACR, OARSI, Cochrane database), medical exercises were singled out as a key non-pharmacological method of OA treatment that is highly recommended for pain reduction and improving joint function $(8,13,14)$. This is a non-invasive and low-cost treatment method whose primary effect is short-term, while long-term positive effects are only achieved through great patient adherence to treatment.

Patient education and training performed with the purpose of implementing exercises in the activities of daily living (ADL) and lifestyle changes is extremely important in achieving these results. The reason for the suboptimal quality of OA treatment with NPT is the patients' motivation to exercise, which may ultimately create a barrier in the implementation of clinical evidence and guidelines.

After studying the significance and effect of medical exercises as a method of non-pharmacological treatment of osteoarthritis, we were interested in what the available medical literature had to say about the socalled new technologies in medical rehabilitation, which most often include the following:

a. High Intensity Laser Therapy (HILT): high output power of the laser beam up to $12 \mathrm{~W}$ enables deep penetration into the tissue and quality pain relief,

b. Extracorporeal Shockwave Therapy (ESWT): non-invasive extracorporeal shockwave therapy for musculoskeletal pain,

c. Radio frequency (RF): targeted high-frequency electromagnetic energy directed at the selected tissue as a non-thermal method of cellular biostimulation. Most common indications include: localised muscle twitches, trigger points, myalgia, tendinitis, neck pain and posttraumatic oedema, with an extremely rapid effect,

d. High-intensity electromagnetic field (the socalled electromagnetic therapy super inductive system, SIS): technology based on a high-intensity electromagnetic field that has a positive effect on human tissue. Therapeutic effects include pain reduction, fracture treatment, myorelaxation, myostimulation, and joint mobilisation.

In all of the found studies, which were relatively well prepared and performed, the most frequently moni- fesionalaca. Liječenje OA ocijenjeno je kao kompleksno i multimodalno (14).

Dakle, na temelju svega navedenoga, kao i prema svim analiziranim smjernicama u spomenutim publikacijama (EULAR, ESCEO, ACR, OARSI, Cochraneova baza podataka), medicinske su vježbe izdvojene kao ključna nefarmakološka metoda liječenja OA koja ima snažnu preporuku s obzirom na smanjenje boli i poboljšanje funkcije zgloba $(8,13,14)$. Riječ je o neinvazivnoj, a jeftinoj metodi liječenja čiji je prvotni učinak kratkoročan, dok je za dugoročan pozitivni učinak potrebna dobra adherencija bolesnika.

Edukacija bolesnika radi implementacije vježbi u aktivnosti dnevnog življenja (ADŽ) i promjenu životnog stila iznimno je važna pri postizanju tih rezultata. Suboptimalnoj kvaliteti liječenja OA NFL-om razlog je upravo motivacija bolesnika za vježbanje, što na kraju može stvoriti barijeru pri implementaciji kliničkih dokaza i smjernica.

Nakon proučavanja značenja i učinka medicinskih vježbi kao metode nefarmakološkog liječenja osteoartritisa zanimalo nas je što dostupna medicinska literatura navodi o tzv. novim tehnologijama u medicinskoj rehabilitaciji, među koje se najčešće ubrajaju:

a. Laser visokog intenziteta (engl. High Intensity Laser Therapy - HILT): visoka izlazna snaga laserskog snopa do $12 \mathrm{~W}$ omogućava duboko prodiranje u tkivo i kvalitetno ublažavanje boli

b. Udarni val (engl. Extracorporeal Shockwave Therapy - ESWT): neinvazivna izvantjelesna terapija udarnim valom za boli mišićno-koštanog sustava

c. Radiofrekvencija (RF): usmjerena elektromagnetska energija visoke frekvencije upućena u odabrano tkivo kao netermalna metoda stanične biostimulacije. Najčešće indikacije jesu: lokalizirani grčevi mišića, okidačke (engl. trigger) točke, mialgija, tendinitis, bol u vratu i posttraumatski edem, uz vrlo brzi učinak

d. Elektromagnetsko polje visokog intenziteta (tzv. superinduktivni sustav - SIS): tehnologija zasnovana na elektromagnetskom polju visokog intenziteta koja pozitivno djeluje na ljudsko tkivo. Terapijski učinci uključuju smanjenje boli, liječenje fraktura, miorelaksaciju, miostimulaciju i mobilizaciju zglobova.

U svim nađenim studijama, koje su bile relativno dobro osmišljene i izvedene, najčešće praćeni parametri mjere ishoda liječenja bili su: razina oštećenja (morfologija i funkcija), bol i funkcionalne mogućnosti. Pritom su kao instrumenti ishoda liječenja upotrijebljeni: vizualno-analogna ljestvica boli (VAS), WOMAC-ov indeks i Lequesneov indeks (LI) stupnja nesposobnosti, a kao instrument za klasifikaciju težine OA Kellgren-Lawrenceov radiografski indeks, koji su omogućili objektivne procjene učinka liječenja.

U prvome sustavnom pregledu učinka HILT-a na OA koljena 2018. g. Justyna Wyszyńska i suradnici 
tored parameters of the treatment outcome measure were the following: level of impairment (morphology and function), pain, and functional abilities. The following instruments were used as instruments of treatment outcome: the visual analogue scale (VAS) of pain intensity, the Western Ontario and McMaster Universities Arthritis Index (WOMAC), the Lequesne Index (LI) of the level of severity, and the Kellgren-Lawrence radiographic index as an instrument for OA severity classification, all of which have enabled objective evaluations of treatment effect to be performed.

In the first systematic review of the effect of HILT on knee OA performed in 2018, Justyna Wyszyńska et al. included 6 studies in the analysis (15). All of the selected studies have confirmed that HILT was useful in the treatment of knee OA because it has reduced pain and increased functional abilities of patients suffering from the said disease (15).

At the same time, it was necessary to draw attention to the difference between the efficacy of the new HILT therapy and previously used LLLT therapy in the treatment of knee OA. In 2014, Kheshie et al. conducted a randomised control study in which they have compared these two energetically different lasers during their application in NPT of patients suffering from knee OA (16). After the treatment was applied for 6 weeks, the result showed that both HILT and LLLT in combination with exercise have proved to be an effective modality of OA treatment, with the results of pain reduction which were obtained using VAS and according to the WOMAC index. HILT used in combination with exercise was more effective than LLLT used in combination with exercise, and both treatment modalities showed better results than just using exercise alone when it came to patients suffering from knee OA (16).

The emergence of new technologies has brought about common comparisons with the methods of treatment which were used prior to their occurrence, although the name "conventional physical therapies" rarely specified which therapeutic methods were implied under this term. Thus, in 2018, Nazari et al. published the results of a randomised control study in which they have compared the effect of HILT and conventional physical therapy with exercise on the Iranian urban population, which showed that HILT was more effective in the treatment of pain measured through VAS and increasing range of motion (17).

The results of their study have shown that HILT was a safe and well-tolerated method in the treatment of patients suffering from knee OA. In addition to this, high-intensity laser therapy used in combination with exercise has proved to be more effective than conventional physical therapy used in combination with exercise or exercise alone in terms of pain relief and improvement of functional ability of patients suffering from knee OA, and it proved to be effective in other uključili su u analizu 6 studija (15). Sve odabrane studije potvrdile su da je HILT bio koristan u tretmanu OA koljena, jer je smanjio boli i povećao funkcionalne mogućnosti u bolesnika s tom bolesti (15).

Istodobno, pokazalo se potrebnim upozoriti na razliku između učinkovitosti nove terapije HILT-om i prije rabljene terapije LLLT-om u liječenju OA koljena. Godine 2014. Kheshie i suradnici proveli su randomiziranu kontrolnu studiju u kojoj su usporedili ta dva energetski različita lasera tijekom njihove primjene $u$ NFL-u bolesnika s OA koljena (16). Nakon tretmana tijekom 6 tjedana rezultat je pokazao da su i HILT i LLLT u kombinaciji s vježbama učinkovit modalitet liječenja OA, uz smanjenje boli na VAS-u i prema indeksu WOMAC-a. HILT u kombinaciji s vježbama bio je učinkovitiji od LLLT-a kombiniranoga s vježbama, a oba modaliteta liječenja bila su bolja nego samo vježbe u bolesnika s OA koljena (16).

Pojava novih tehnoloških mogućnosti dovela je do čestih usporedba $s$ dotadašnjim načinima liječenja, premda se pod nazivom „konvencionalne fizikalne terapije" rijetko kad specificiralo o kojim je terapijskim metodama riječ. Tako su 2018. g. Nazari i suradnici objavili rezultate randomizirane kontrolne studije $\mathrm{u}$ kojoj su na iranskoj urbanoj populaciji uspoređivali učinak HILT-a i konvencionalne fizikalne terapije uz vježbanje te pokazali da je HILT bio učinkovitiji u liječenju boli mjerene VAS-om i povećanju opsega pokreta (17).

Njihovi su rezultati pokazali da je HILT u bolesnika s OA koljena siguran i dobro podnošljiv način liječenja. Također, terapija laserom visokog intenziteta $\mathrm{u}$ kombinaciji s vježbama pokazala se učinkovitijom od konvencionalne fizikalne terapije kombinirane s vježbama ili od vježbi samih u pogledu olakšanja boli i poboljšanja funkcije bolesnika s OA koljena, ali i u drugim stanjima (17). Premda je ova studija bila daleko bolje planirana i kompleksnije provedena, slične rezultate na sličnom broju bolesnika (Nazari - 95 bolesnika) mogli smo vidjeti i u nekim jednostavnijim studijama poput, npr., studije Ilieve (18), koja je 2016. g. provedena na 72 bolesnika, kao i studije naših autora Nives Štiglić-Rogoznice i suradnika (19), koji su ispitivanjem obuhvatili 96 ispitanika. Sve to potvrđuje HILT kao uspješnu, učinkovitu i neštetnu metodu liječenja OA koljena.

Uporaba izvantjelesnog udarnog vala (ESWT) u NFL-u OA evaluirana je u većem broju literaturnih navoda, među kojima se ističu sustavni pregled i metaanaliza Lija i suradnika iz 2019. g. (20) koji su, pregledavajući brojne baze podataka (PubMed, Embase, Web of Science, ResearchGate, Cochrane Library), zaključili da su učinci ESWT-a pri tretmanu OA koljena bolji od placeba i drugih fizikalnih terapija (nisu specificirali što je time bilo obuhvaćeno). Osim ublažavanja boli, 
conditions as well (17). Although this study was planned in a far better way and implemented in a more complex manner, similar results on a similar number of patients (Nazari - 95 patients) could be found in some simpler studies such as, for example, the study conducted by Ilieva (18), which was performed in 2016 on 72 patients, as well as studies conducted by Croatian authors such as Nives Štiglić-Rogoznica et al. (19), which included 96 subjects. All of the aforementioned confirms that HILT is a successful, effective, and harmless method of knee OA treatment.

The use of extracorporeal shockwave therapy (ESWT) in NPT of OA has been evaluated in a number of literature citations, including a systematic review and meta-analysis performed in 2019 by Lee et al. (20) who have concluded, by reviewing numerous databases (PubMed, Embase, Web of Science, ResearchGate, Cochrane Library), that the effects of ESWT in the treatment of knee OA were better than placebo and other physical therapies (they did not specify what was covered by this). In addition to pain relief, ESWT has increased knee joint mobility and decreased the Lequesne Index (LI) and the WOMAC index (20). Evidence has confirmed that ESWT is a quality choice for knee OA treatment. However, due to the lack of relevant high-quality literature evidence, similar previous meta-analyses, and the fact that some studies have not been used to achieve quality evidence, it is recommended to continue proving these results (20).

A similar methodology for studying systematic reviews and meta-regression analysis of randomised criteria studies was applied in a 2019 study conducted by Liao et al., which included 50 studies with 4844 patients and the conclusion was that ESWT was beneficial for patients suffering from knee OA (21). This is also followed by common objections that the dosage of the shockwave, and in particular the energy level used, the duration of individual procedures and the overall treatment may contribute differently to the effectiveness of treatment. The authors conclude that shockwave therapy can be used to relieve pain and improve functional abilities of patients suffering from knee OA. In the use of this treatment method, the radial shockwave, applied in the long duration of treatment, is more effective for recovery of functional abilities than the application of a focused shockwave, especially when it comes to knee OA (21).

The studies that have tried to assess which part of the joint is the most suitable for the application of ESWT with the best therapy results are also quite interesting. Thus, a study conducted by Zhong et al. in 2019, mentioned a case of a four-week long treatment of knee OA with low-dose ESWT that proved to be better than placebo treatment in pain relief and improvement of functional abilities in patients with mild to moderate knee OA, but it also had some adverse effects on the articular cartilage (22). In everyday practice, we are of-
ESWT je povećao pokretljivost zgloba koljena te snizio Lequesneov indeks (LI) i indeks WOMAC-a (20). Dokazi su potvrdili da je ESWT kvalitetan odabir za tretman OA koljena. Međutim, zbog nedostatka relevantnih visokokvalitetnih literaturnih dokaza i sličnih prethodnih metaanaliza te činjenice da neke studije nisu iskorištene za postizanje kvalitetnih dokaza preporučuje se nastavak dokazivanja tih rezultata (20).

Sličnu metodologiju proučavanja sustavnih pregleda i metaregresijske analize randomiziranih kriterijskih studija primijenio je Liao sa suradnicima 2019. g, a uključivala je 50 istraživanja s 4844 bolesnika te je donesen zaključak da je terapija ESWT-om korisna za bolesnika s OA koljena (21). Pritom postoje i uobičajeni prigovori da doziranje udarnog vala, a osobito upotrijebljena razina energije, trajanje pojedinih procedura i ukupni tretman mogu različito pridonositi učinkovitosti liječenja. Autori zaključuju da se terapija udarnim valom može iskoristiti za ublažavanje boli i poboljšanje funkcionalnih mogućnosti u bolesnika $\mathrm{s}$ OA koljena. Pritom je radijalni udarni val, primijenjen dugim trajanjem tretmana, učinkovitiji za oporavak funkcionalnih mogućnosti od aplikacije fokusiranog udarnog vala, osobito kod OA koljena (21).

Zanimljiva su i istraživanja koja su pokušala ocijeniti koji je dio zgloba najpogodniji za aplikaciju ESWT-a uz najbolje rezultate terapije. Tako Zhong i suradnici 2019. g. navode podatak o četverotjednom tretmanu OA koljena niskim dozama ESWT-a koji se pokazao kvalitetnijim od tretmana placebom za olakšanje boli i poboljšanje funkcionalnih mogućnosti u bolesnika $\mathrm{s}$ blagim do umjerenim tegobama zbog OA koljena, ali je imao i neke negativne učinke na zglobnu hrskavicu (22). U svakodnevnoj se praksi često susrećemo s pitanjem koji dio OA zgloba treba tretirati, a odgovor možda nalazimo u članku Choua i suradnika (23), koji navode da su njihovi rezultati pokazali kako je suphondralna kost odlična meta za tretman ESWT-om u odnosu prema zglobnoj hrskavici kod ranog OA koljena, sa znatno boljim učinkom liječenja ovom metodom NFL-a (23).

Među brojnim literaturnim navodima o ESWT-u ističe se jedan koji je usmjeren na ocjenu podnošljivosti ove terapije, često percipirane kao neugodne za bolesnike. Tako je Ying-Chun Wang sa suradnicima u sustavnom pregledu i metaanalizama iz 2019. g. zaključila da je primjena ESWT-a za tretman OA koljena nedvojbeno učinkovita na smanjenje boli i poboljšanje fizičke funkcije zgloba tijekom 12 mjeseci u svim analiziranim člancima, i to uz pojavu tek manjih komplikacija poslije tretmana udarnim valom (24). Međutim, unatoč pregledu brojnih članaka i ovim je autorima ostalo nejasno koja se frekvencija i koje razine doziranja udarnog vala moraju primijeniti da bi se postignulo maksimalno poboljšanje nalaza (24). 
ten faced with the question of which part of the OA joint should be treated, and the answer may be found in the article written by Chou et al. (23), who state that their results have shown that the subchondral bone was an excellent target for ESWT treatment in comparison to articular cartilage in the early stages of knee OA, with a significantly better effect of treatment achieved with this method of NPT (23).

Among the numerous literature citations on ESWT, there is one that particularly stands out and is focused on assessing the tolerability of this therapy, which is often perceived as uncomfortable for patients. Therefore, in the 2019 systematic review and meta-analysis conducted by Ying-Chun Wang et al., it was concluded that the use of ESWT in the treatment of knee OA is undoubtedly effective in reducing pain and improving the physical function of joints during a 12-month period in all analysed articles, with the emergence of minor complications following the period of shockwave treatment (24). However, despite the review of a number of articles, these authors are also unsure of the exact frequency and levels of shockwave dosage which must be applied in order to achieve the maximum improvement of the findings (24).

In literature, there is a small number of quality data on the use of radio frequency (RF) in the treatment of $\mathrm{OA}$, as it is a relatively new and expensive technology, so the availability of this method and the possibilities of OA treatment are currently scarce. Therefore, there are no systematic review papers in the Cochrane Library or in the PEDro database.

However, by conducting a literature search, we have managed to find an article written by Canadian authors who have concluded, by analysing the results of 33 studies, 13 of which were randomised controlled trials with 1512 patients, that current evidence confirms that RF modalities in knee OA treatment can reduce pain and improve joint function as well as the quality of life specific for this disease in the period during 3 to 12 months, with minimal localised complications (25). This suggests that RF modalities may be an effective adjuvant therapy for patients suffering from knee OA who do not respond to conservative therapy treatments.

The authors leave open the possibility for a better response to be provided by a future randomised controlled study of a larger sample and long-term followup, which will directly compare the 3 primary RF modalities and guarantee their clinical efficacy and advantage for knee OA (25).

In another paper written by American authors, primarily anaesthesiologists, it was stated that, based on recent studies, the current recommendation for $\mathrm{RF}$ treatment of $\mathrm{OA}$ is related to the inclusion of candidates which were deemed unsuitable for surgical treatment, patients with severe and persistent knee pain, or patients with existing contraindications for other OA treatment options (26).
$\mathrm{O}$ uporabi radiofrekvencije (RF) pri liječenju $\mathrm{OA} \mathrm{u}$ literaturi postoji malo kvalitetnih podataka, jer je riječ o relativno novoj i skupoj tehnologiji tako da su i dostupnost ove metode i mogućnosti liječenja OA zasad malene. Zbog toga nema ni sustavnih preglednih radova u Cochraneovoj knjižnici ni u bazi PEDro.

Ipak, pretraživanjem literature našli smo jedan članak kanadskih autora koji su, analizirajući rezultate 33 studije od kojih 13 randomiziranih kontrolnih studija s 1512 bolesnika, zaključili da sadašnji dokazi potvrđuju kako modaliteti RF-a u liječenju OA koljena mogu smanjiti bol te poboljšati funkciju zgloba i kvalitetu života specifičnu za bolest tijekom 3 do 12 mjeseci, uz minimalne lokalizirane komplikacije (25). Time upućuju na to da su modaliteti RF-a, možda, učinkovita dodatna terapija za bolesnike s OA koljena koji ne reagiraju na konzervativne tretmane.

Autori ostavljaju otvorenom mogućnost da kvalitetniji odgovor pruži buduća randomizirana kontrolirana studija većeg uzorka i dugoročnog praćenja, koja će izravno uspoređivati 3 primarna modaliteta RF-a te jamčiti njihovu kliničku učinkovitost i prednost za OA koljena (25).

U još jednom radu američkih autora, ponajprije anesteziologa, navodi se da se temeljem recentnih studija sadašnja preporuka za tretman OA primjenom RF-a odnosi na uključivanje kandidata koji nisu prikladni za kirurško liječenje, bolesnika s teškom i tvrdokornom boli u koljenu ili bolesnika s postojećim kontraindikacijama za druge opcije liječenja OA (26).

Za primjenu superinduktivnog sustava (SIS) vrijede slične napomene kao i za RF: zasad nema kvalitetnih podataka u velikim bazama. Dostupni podatci temelje se jedino na istraživanjima koja sponzoriraju proizvođači medicinske opreme pa je istaknuta moguća pristranost $\mathrm{u}$ iskazivanju rezultata. Pritom se navode $\mathrm{i}$ problemi s trenutačnom dostupnosti ovoga terapijskog modaliteta, kvalitetnim prikupljanjem podataka te budućim publiciranjem dobivenih rezultata. Metaanaliza Chena i suradnika, kao jedini članak koji problematizira uporabu elektromagnetskog polja visokog intenziteta (PEMF), pokazala je da je, usprkos tomu što nije bilo nikakvih prednosti postupka s obzirom na bol i ukočenost, terapija PEMF-om navedena je kao korisna za poboljšanje kliničkih simptoma - fizičke funkcije u bolesnika s OA koljena (27).

To bi moglo značiti da terapija PEMF-om može biti koristan i ekonomičan adjuvantni tretman za nekirurški postupak pri liječenju OA koljena. Autori navode da je potrebno daljnje istraživanje kako bi se odredili optimalna učestalost, intenziteti liječenja, režim tretmana i trajanje terapije PEMF-om (27).

$\mathrm{Na}$ kraju ovog pregleda literature kratko se osvrćemo i na neke podatke medicine temeljene na dokazima koji se odnose na tradicionalne metode NFL-a OA, a 
For the application of the super inductive system (SIS), similar remarks apply as for the RF: so far there is no quality data in large databases. The available data are based only on research sponsored by medical device manufacturers, so, in this regard, the possible bias in presenting the results was highlighted. Issues with the current availability of this therapeutic modality, quality data collection and future publication of the obtained results are also mentioned. A meta-analysis performed by Chen et al., as the only paper to problematise the use of high-intensity electromagnetic fields (pulsed electromagnetic field, PEMF), showed that, although there were no benefits to the procedure in terms of pain and stiffness, PEMF therapy was cited as useful for improving clinical symptoms - physical functions in patients suffering from knee OA (27).

This could mean that PEMF therapy may be a useful and cost-effective adjuvant treatment for a non-surgical procedure in the treatment of knee OA. The authors state that further research is required in order to determine the optimal frequency, treatment intensities, treatment regimen, and duration of PEMF therapy (27).

At the end of this literature review, we will also briefly touch on some EBM data relating to traditional methods of NPT of OA, which we have formerly regarded as being of great importance in the treatment of our patients suffering from $\mathrm{OA}$.

One of the most commonly used methods of NPT of $\mathrm{OA}$ in everyday practice is therapeutic ultrasound (US) which is often used with sonophoresis. Wu et al. have published a systematic review and meta-analysis on this topic (28). The results of 15 studies were evaluated, including 3 studies with sonophoresis, which included 1074 patients and monitored outcomes using VAS of pain intensity, the WOMAC index, the Lequesne Index, and range of motion (ROM). Their conclusion is that therapeutic ultrasound is a safe and effective treatment for pain relief and the improvement of functional abilities of patients suffering from knee $\mathrm{OA}$, and that sonophoresis does not provide additional benefits in terms of functional improvement, but can be slightly more successful than conventional ultrasound in terms of pain relief (28).

By researching the effects of cryotherapy treatment on patients suffering from knee OA in systematic reviews and randomised controlled trials, Dantas et al. have concluded that there is a lack of quality studies required to draw any conclusions about the effectiveness of cryotherapy on pain and physical function of individuals suffering from knee OA (29). We have also found an interesting article on the use of cold in the treatment of knee OA, which will serve as a mere experimental model. Radnovich et al. have published a randomised, double-blind, placebo-controlled study with a sixmonth follow-up of patients undergoing cryoneurolysis of the infrapatellar branch of the saphenous nerve (IPB$\mathrm{SN}$ ) of the painful knee, with outcome monitoring in za koje smo dosad mislili da imaju veliko značenje u liječenju naših bolesnika s OA.

Jedna od najčešće rabljenih metoda NFL-a OA u svakodnevnoj praksi jest terapijski ultrazvuk (UZ) i uz njega često upotrijebljena sonoforeza. Wu i suradnici objavili su sustavni pregled i metaanalizu o toj temi (28). Evaluirani su rezultati 15 studija, uključujući 3 sa sonoforezom, koje su obuhvatile 1074 bolesnika i pratile ishode na VAS-u za bol, indeks WOMAC-a, Lequesneov indeks i opseg pokreta (ROM). Njihov je zaključak da je terapijski UZ siguran i učinkovit tretman za ublažavanje boli i poboljšanje funkcije kod bolesnika s OA koljena te da pritom sonoforeza ne ostvaruje dodatne prednosti u pogledu funkcionalnog poboljšanja, ali može nešto više smanjiti bol od konvencionalnog UZ-a (28).

Istražujući učinke liječenja krioterapijom bolesnika s OA koljena u sustavnim pregledima i randomiziranim kontrolnim studijama, Dantas i suradnici zaključili su da nema dovoljno kvalitetnih studija kako bi se donijeli bilo kakvi zaključci o učinkovitosti krioterapije na bol i fizičku funkciju pojedinaca s OA koljena (29). Pritom smo našli i zanimljiv članak o primjeni hladnoće u liječenju OA koljena, koja neće biti više od eksperimentalnog modela. Naime, Radnovich i suradnici objavili su randomizirano, dvostruko slijepo istraživanje kontrolirano placebom sa šestomjesečnim praćenjem bolesnika kojima je napravljena krioneuroliza infrapatelarne grane nervusa safenusa (IPBSN) bolnog koljena, uz praćenje ishoda prema indeksu WOMAC-a i na VAS-u boli bolesnika (30). Autori su zaključili da je krioneuroliza IPBSN-a rezultirala statistički značajnim smanjenjem boli u koljenu i poboljšanjem kliničke slike u odnosu prema liječenju placebom, s do 150 dana trajanja učinka, a liječenje se pokazalo sigurnim i dobro podnošljivim za bolesnike s OA koljena (30).

Provođenje tradicionalne terapije ventuzama (engl. cupping therapy) istraživala je Yu-Ling Wang sa suradnicima te su našli čak 5 studija koje su ispunjavale kriterije za njihovu evaluaciju dokaza. Zaključili su da postoje tek slabi dokazi koji bi poduprli hipotezu da ventuze (cupping-terapija) imaju bilo kakve korisne učinke na smanjenje intenziteta boli i poboljšanje fizičke funkcije pojedinaca s OA koljena (31).

Primjenu balneoterapije (SPA-terapije) kao dijela NFL-a OA problematizirali su talijanski autori jer je upravo u Italiji takav način liječenja OA vrlo popularan. Zaključili su da nema dovoljno snažnih dokaza koji bi u njihovu istraživanju i pretraživanju literature o toj temi naveli SPA-terapiju kao važan način rehabilitacije (32).

I na kraju navodimo podatak o uporabi ortoza koje se uvijek spominju kao dio NFL-a OA. Prema literaturnim podatcima Rodriguez-Merchana i suradnice, idealna je opcija za primjenu ortoza u bolesnika s OA 
accordance with the WOMAC index and VAS of pain intensity (30). The authors have concluded that cryoneurolysis of the IPBSN resulted in a statistically significant reduction of knee pain and an improvement in the clinical features in comparison to placebo treatment, with its effectiveness lasting up to 150 days, and the treatment proved to be a safe and well-tolerated method for patients suffering from knee OA (30).

The use of traditional cupping therapy was researched by Yu-Ling Wang et al. and they have found as many as 5 studies which met the criteria for their evaluation of evidence. They have concluded that there is still a lack of strong evidence which would support the hypothesis that cupping therapy has any beneficial effects in reducing pain intensity and improving the physical function of individuals suffering from knee OA (31).

The use of balneotherapy (spa therapy) as part of NPT of OA has been problematised by Italian authors because this method of OA treatment is very popular in Italy. They have concluded that there was a lack of strong evidence required to include spa therapy as an important method of rehabilitation in their research and literature search on the topic (32).

Lastly, we have mentioned the use of orthoses that are always included as part of NPT of OA. According to the data found in the paper written by RodriguezMerchan et al., the ideal option for the use of orthoses in patients suffering from knee OA remains undetermined because it lacks long-term concrete conclusions and stronger recommendations (33).

\section{DISCUSSION AND CONCLUSION}

Nowadays, OA is recognised as a disease with a significant adverse effect on the function and quality of life, psychological health, work ability, and the ability of active participation in the community. From the viewpoint of an individual suffering from OA, the most important effects of the disease, along with functional impairment and pain, are prolonged fatigue and reduced work ability (2). Due to pain, poor functional ability status, and concomitant depression and fatigue, patients suffering from rheumatic diseases, including those suffering from OA, are more likely to have a sedentary lifestyle $(1,2)$. The aggravating circumstance in the lives of these patients is also the occurrence of numerous comorbidities, which further increase the risk of morbidity of these patients. Unemployment, sick leave and inability to work rates are extremely high in patients suffering from $\mathrm{OA}$, which consequently affects their economic (in)security and (in)ability to actively participate in social activities. The objectives of OA treatment are clear and, according to available guidelines, include all forms of NPT aimed at reducing pain, morning stiffness, swelling, disease progression, and negative psychological impact, thus maintaining a high level of physical, psychological, and social quality of life when it comes to these patients $(1-4)$. koljena i dalje neodređena, jer joj nedostaju dugoročni konkretni zaključci i snažnije preporuke (33).

\section{RASPRAVA I ZAKLJUČAK}

Danas je OA prepoznat kao bolest sa znatnim negativnim učinkom na funkciju i kvalitetu života, psihološko zdravlje, radnu sposobnost te sposobnost aktivnog sudjelovanja u zajednici. Sa stajališta oboljelog od OA najvažniji učinak bolesti, uz funkcionalno oštećenje i bol, jesu dugotrajan umor i smanjena radna sposobnost (2). Zbog boli, lošega funkcionalnog statusa te popratne depresije i umora bolesnici s reumatskim bolestima, pa tako i oni s OA, češće provode sjedalački način života $(1,2)$. Otegotna im je okolnost i pojava brojnih komorbiditeta, koji dodatno povisuju rizik od morbiditeta tih bolesnika. Stope nezaposlenosti, bolovanja i radne nesposobnosti izrazito su visoke u bolesnika s OA, što onda utječe i na njihovu ekonomsku (ne)sigurnost i na (ne)mogućnost aktivnog sudjelovanja u društvenom životu. Ciljevi liječenja OA jasni su i, prema dostupnim smjernicama, uključuju sve oblike NFL-a koji su usmjereni na smanjenje boli, jutarnje zakočenosti, otekline, progresije bolesti i negativnoga psihičkog utjecaja, čime se onda kod bolesnika održava visoka razina fizičke, psihičke i socijalne kvalitete života $(1-4)$.

Nikako ne smijemo zaboraviti na aktivnosti koje djeluju na smanjenje umora, osnažuju bolesnika za prikladno nošenje s posljedicama bolesti te preveniraju komorbiditete. Treba imati na umu da se sve te aktivnosti provode radi osposobljavanja za samostalno i aktivno sudjelovanje u zajednici, a prema Svjetskoj zdravstvenoj organizaciji (SZO), to i jest glavni cilj NFL-a (1).

Imajući na umu bolesnikov doživljaj utjecaja bolesti na kvalitetu fizičkog, psihičkog i socijalnog zdravlja, biopsihosocijalni model bolesti SZO-a, poznatiji kao ICF (engl. International Classification of Functioning, Disability and Health), trebao bi se rabiti za evaluaciju bolesnika i planiranje NFL-a reumatskih bolesti, pa tako i OA (34).

A što nam je pretraživanje literature donijelo kao odgovor na pitanje koji su oblici NFL-a najbolji, najučinkovitiji i najčešće preporučeni od stručnjaka u procesu liječenja OA? Postupci koji su dobili najvišu ocjenu i imali najviše kvalitetnih dokaza o učinkovitosti na pojedinca spadaju u kategoriju koju nazivamo medicinskim vježbama / kinezioterapijom / terapijskim vježbama / tjelesnom aktivnošću $(10-14)$. Nedvojbeno je dokazano da su ti postupci najkorisniji oblik NFL-a OA, iako još nije definirano u kojem bi se okviru oni primjenjivali s obzirom na precizno određivanje vrsta vježbi, učestalost vježbanja, intenzitet provođenja terapije i trajanje takvog liječenja. Sve smjernice snažno preporučuju i neke, nama manje poznate oblike medicinskog vježbanja kao što je Tai Chi. Ipak, 
We must not forget the activities that reduce fatigue, empower the patient to cope with the consequences of the disease and prevent comorbidities. One should bear in mind that all of these activities are carried out for the purpose of training the patient for an independent and active participation in the community, which is the main objective of NPT, according to the World Health Organization (WHO) (1).

Given the patient's experience of the impact of disease on the quality of physical, psychological and social health, the biopsychosocial model of the disease developed by WHO, better known as ICF (International Classification of Functioning, Disability and Health), should be used for patient evaluation and planning of NPT of rheumatic diseases, including OA (34).

What have we found by doing a literature search in response to the question of which forms of NPT are the best, most effective, and most commonly recommended by experts in the OA treatment process? The procedures that have received the highest score and had the highest quality evidence of efficacy per individual fall into the category known as medical exercises / kinesiotherapy / therapeutic exercises / physical activity (10 14). It has been unequivocally proven that these procedures are the most useful forms of NPT of OA, although the framework in which they would be used is not yet defined given the precise determination of exercise types, exercise frequency, therapy intensity and duration of such treatment. All guidelines strongly recommend certain forms of medical exercise we are not that familiar with, such as Tai Chi. However, according to the 2019 American College of Rheumatology (ACR) guidelines, these exercises, which are not that well-defined, should be done with caution because, for example, yoga exercises can cause decompensation of a preexisting knee OA (35). These guidelines also contain precise general recommendations on exercise dosage: aerobic training of medium intensity - 30 minutes per day, progressive exercises of medium to strong intensity used to strengthen the main muscle groups -8 to 12 repetitions at least 2 times a week (35).

All of this is related to another factor that is extremely important as a measure of treatment success, and that is adherence to treatment. Its level is still very low for this form of treatment. Although EBM did not precisely define it in the analysed reviewed articles, we are well aware of this due to everyday practice and patient surveys.

Nowadays, the use of numerous forms of modern technologies in NPT of OA is highlighted in all guidelines. The articles that we have reviewed proved that all forms of new technologies (HILT, ESWT, RF, SIS) have an enviable effectiveness in improving the clinical findings and functional abilities of monitored patients, both in monotherapy and in combined methods of treatment (usually used in combination with medical exercises) $(15-27)$. prema smjernicama ACR-a iz 2019. g., treba biti oprezan s tim slabije definiranim vježbama, jer, primjerice, vježbe joge mogu izazvati dekompenzaciju postojećeg OA koljena (35). U smjernicama postoje i precizne opće preporuke o doziranju vježbi: aerobni trening srednjeg intenziteta - 30 minuta na dan, progresivne vježbe snaženja glavnih mišićnih skupina srednjega do jakog intenziteta - 8 do 12 ponavljanja barem 2 puta na tjedan (35).

Uza sve to veže se još jedan čimbenik koji je iznimno važan kao mjera uspješnosti liječenja, a to je adherencija. Njezina je razina i dalje veoma niska za taj oblik liječenja. Premda ju EBM nije precizno definirao u analiziranim pregledanim člancima, to najbolje znamo iz svakodnevne prakse i anketiranja svojih bolesnika.

Primjena brojnih oblika moderne tehnologije $u$ NFL-u OA danas se naglašava u svim smjernicama. Članci koje smo proučavali dokazali su da svi oblici novih tehnologija (HILT, ESWT, RF, SIS) imaju zavidnu učinkovitost $\mathrm{u}$ ostvarivanju poboljšanja kliničkog nalaza i funkcionalnih mogućnosti praćenih bolesnika, kako u monoterapiji tako i u kombiniranim načinima liječenja (najčešće uz medicinske vježbe) $(15$ - 27).

Pregled literature koji smo prije citirali nije ostavio previše dobrih dojmova u svezi s uporabom klasične ili konvencionalne fizikalne terapije (28), kao ni nekih tradicionalnih načina liječenja (krioterapija, cupping, ortoze) $(29$ - 33). Premda nema razine dokaza o njihovu učinku na bolesnike s $\mathrm{OA}$, nije rečeno niti da ne postoje dokazi o njihovoj učinkovitosti. S druge strane, prema smjernicama OARSI-ja iz 2019. g., hidroterapija je imala velik konsenzus stručnjaka (više od 75\%) kao preporuka za NFL OA koljena, uz napomenu da se ne preporučuje bolesnicima sa znatnijim kardiovaskularnim komorbiditetom iako se na temelju iskazanih rezultata Bernettija i suradnika to ne bi moglo zaključiti (32).

Dakle, i te se metode može u nekim situacijama iskoristiti za postizanje terapijskog boljitka, kao i konvencionalnu terapiju koja u prezentiranim člancima nije izrijekom specificirana. Također, nije navedeno da je ona neučinkovita, nego je snaga dokaza o toj učinkovitosti bila slaba, što je rezultat malenog broja kvalitetnih studija i publikacija o toj temi. Ondje gdje je bilo ponuđeno dovoljno kvalitetnih studija, i snaga dokaza bila je naglašenija, tako da konvencionalna terapija ima pozitivnu i uvjetnu preporuku u smjernicama ACR-a (35) i ESCEO-a (8), dok su smjernice OARSI-ja (36) u tom pogledu neodređene. Na temelju iskustava stručnjaka sve se te procedure i dalje mogu preporučiti kao priprema za medicinsku vježbu u sklopu multimodalnog pristupa liječenju OA, iako postoji manjak znanstvenih dokaza, a spomenute smjernice ne daju valoriziranu preporuku.

Stoga možemo zaključiti da nam moderne tehnologije u NFL-u OA pružaju veći izbor pasivnih oblika 
The literature review that we have cited earlier did not give a lot of good impressions regarding the use of traditional or conventional forms of physical therapy (28), and the same can be said for certain traditional methods of treatment (cryotherapy, cupping, orthoses) $(29-33)$. Although there is no level of evidence for their effect on patients suffering from OA, none of the information suggest that there is no evidence of their effectiveness. On the other hand, according to the 2019 Osteoarthritis Research Society International (OARSI) guidelines, hydrotherapy had a strong consensus of experts (more than 75\%) as a recommendation for NPT of knee OA, with a note that it is not recommended for patients with significant cardiovascular comorbidity, although, based on the results of Bernetti et al., this could not be concluded (32).

Thus, these methods can also be used in some situations in order to achieve therapeutic improvement, as well as conventional therapy, which is not explicitly specified in the presented articles. Also, it is not stated that this therapy is ineffective, but that the strength of the evidence on this effectiveness was weak, which is the result of a small number of quality studies and publications on the topic. In cases in which sufficient quality studies were provided, the strength of the evidence was more pronounced. Therefore, conventional therapy has a positive and conditional recommendation in the ACR (35) and ESCEO (8) guidelines, while the OARSI guidelines (36) are indefinite in this respect. Based on the experience of experts, all these procedures can still be recommended as preparation for medical exercise as part of a multimodal approach to OA treatment, although there is a lack of scientific evidence and the mentioned guidelines do not provide an evaluated recommendation.

Therefore, we can conclude that modern technologies in NPT of OA provide us with a greater choice of passive forms of physical therapy and contribute to the successful treatment of OA. However, a sufficient level of evidence is still non-existent in the aforementioned guidelines for such forms of OA treatment. The results of the cited studies $(15-27)$ are encouraging so far, but until we are provided with a higher level of evidence strength, we cannot simply declare these procedures to be so much better than all other conventional NPT methods.

In conclusion, it is safe to say that all the reviewed methods of NPT have shown a significant level of efficacy in the treatment of OA: they reduced pain and improved the functional abilities and quality of life of the subjects. This confirmed the need to include NPT in all algorithms / procedures / guidelines for OA treatment. fizikalne terapije i pridonose uspješnom liječenju OA. Ipak, još ne postoji dovoljna razina dokaza u prije navedenim smjernicama za takve oblike liječenja OA. Rezultati citiranih studija (15 - 27) zasad ohrabruju, ali sve dok ne dobijemo više razine snage dokaza, ne možemo te procedure jednostavno proglasiti toliko boljima od svih ostalih konvencionalnih metoda NFL-a.

U zaključku možemo reći da su sve proučavane metode NFL-a pokazale izrazitu učinkovitost u liječenju OA: reducirale su bol i poboljšale funkcionalne sposobnosti i kvalitetu života ispitanika. Time je potvrđena i potreba uvrštavanja NFL-a u sve algoritme/postupnike/smjernice liječenja OA.

IZJAVA o SUKobu INTERESA: Autori izjavljuju da nisu u sukobu interesa. 


\section{REFERENCES / LITERATURA}

1. Global Burden of Disease Study 2013 Collaboration. Global, regional, and national incidence, prevalence, and years lived with disability for 301 acute and chronic diseases and injuries in 188 countries, 1990-2013: a systematic analysis for the Global Burden of Disease Study 2013. Lancet. 2015;386(9995): 743-800.

2. Buelt A, Narducci DM. Osteoarthritis management: updated guidelines from the American College of Rheumatology and Arthritis Foundation. Am Fam Physician. 2021;103(2):120-1.

3. Chamberlain R. Hip pain in adults: evaluation and differential diagnosis. Am Fam Physician. 2021;103(2):81-9.

4. Collins AT, Hu G, Newman H i sur. Obesity alters the collagen organisation and mechanical properties of murine cartilage. Sci Rep. 2021;11(1):1626.

5. Grazio S, Ćurković B, Babić-Naglić Đ i sur. Smjernice Hrvatskoga reumatološkog društva za liječenje osteoartritisa kuka i koljena. Reumatizam. 2010;57(1):36-47.

6. Grazio S, Schnurrer-Luke Vrbanić T, Grubišić F i sur. Smjernice za liječenje bolesnika s osteoartritisom kuka i/ili koljena. Fiz Rehabil Med. 2015;27(3-4):330-81.

7. Kucharz EJ, Szanto S, Goycheva MI i sur. Endorsement by Central European experts of the revised ESCEO algorithm for the management of knee osteoarthritis. Rheumatol Int. 2019; 39(7):1117-23.

8. Bruyère $\mathrm{O}$, Honvo $\mathrm{G}$, Veronese $\mathrm{N}$ i sur. An updated algorithm recommendation for the management of knee osteoarthritis from the European Society for Clinical and Economic Aspects of Osteoporosis, Osteoarthritis and Musculoskeletal Diseases (ESCEO). Semin Arthritis Rheum. 2019;49(3):337-50.

9. Chung P-Y, Lin M-T, Chang H-P. Effectiveness of platelet-rich plasma injection in patients with temporomandibular joint osteoarthritis: A systematic review and meta-analysis of randomized controlled trials. Oral Surg Oral Med Oral Pathol Oral Radiol. 2019;127(2):106-16.

10. Collins NJ, Hart HF, Mills KAG. Osteoarthritis year in review 2018: rehabilitation and outcomes. Osteoarthritis Cartilage. 2019;27(3):378-91.

11. Ferreira RM, Duarte JA, Gonçalves RS. Non-pharmacological and non-surgical interventions to manage patients with knee osteoarthritis: an umbrella review. Acta Reumatol Port. 2018; 43:182-200.

12. Ceballos-Laita L, Estébanez-de-Miguel E, Martín-Nieto G i sur. Effects of non-pharmacological conservative treatment on pain, range of motion and physical function in patients with mild to moderate hip osteoarthritis. A systematic review. Complement Ther Med. 2019;42:214-22.

13. Rausch Osthoff A-K, Niedermann K, Braun J i sur. 2018 EULAR recommendations for physical activity in people with inflammatory arthritis and osteoarthritis. Ann Rheum Dis. 2018;77(9):1251-60.

14. Ilieva EM. Are exercise interventions beneficial for people with hip and knee osteoarthritis? - A Cochrane Review summary with commentary. Musculoskelet Sci Pract. 2019;44:102041.

15. Wyszyńska J, Bal-Bocheńska M. Efficacy of high-intensity laser therapy in treating knee osteoarthritis: a first systematic review. Photomed Laser Surg. 2018;36(7):343-53.

16. Kheshie AR, Alayat MSM, Ali MME. High-intensity versus low-laser level therapy in the treatment of patients with knee osteoarthritis: a randomized controlled trial. Lasers Med Sci. 2014;29(4):1371-6.

17. Nazari A, Moezy A, Nejati P, Mazaherinezhad A. Efficacy of high-intensity laser therapy in comparison with conventional physiotherapy and exercise therapy on pain and function patients with knee osteoarthritis: a randomized controlled trial with 12-week follow up. Lasers Med Sci. 2019;34(3):505-16.
18. Angelova A, Iieva EM. Effectiveness of high intensity laser therapy for reduction of pain in knee osteoarthritis. Pain Res Manag. 2016;2016:9163618.

19. Štiglić-Rogoznica N, Stamenković D, Frlan-Vrgoč Lj, AvanciniDobrović V, Schnurrer-Luke Vrbanić T. Analgesic effect of high intensity laser therapy in knee osteoarthritis. Coll Antropol. 2011;35(Suppl. 2):183-5.

20. Li T, Ma J, Zhao T, Gao F, Sun W. Application and efficacy of extracorporeal shockwave treatment for knee osteoarthritis: A systematic review and meta-analysis. Exp Ther Med. 2019;18 (4):2843-50.

21. Liao C-D, Tsauo J-Y, Liou T-H, Chen H-C, Huang S-W. Clinical efficacy of extracorporeal shockwave therapy for knee osteoarthritis: a systematic review and meta-regression of randomized controlled trials. Clin Rehabil. 2019;33(9):1419-30.

22. Zhong Z, Liu B, Liu G i sur. A randomized controlled trial on the effects of low-dose extracorporeal shockwave therapy in patients with knee osteoarthritis. Arch Phys Med Rehabil. 2019;100(9):1695-1702.

23. Chou W-Y, Cheng J-H, Wang CJ-, Hsu S-L, Chen J-H, Huang $\mathrm{C}-\mathrm{Y}$. Shockwave targeting on subchondral bone is more suitable than articular cartilage for knee osteoarthritis. Int J Med Sci. 2019;16(1):156-66.

24. Wang Y-C, Huang H-T, Huang P-J, Liu Z-M, Shih C-L. Efficacy and safety of extracorporeal shockwave therapy for treatment of knee osteoarthritis: a systematic review and meta-analysis. Pain Med. 2020;21(4):822-35.

25. Ajrawat P, Radomski L, Bhatia A, Peng P, Nath N, Gandhi R. Radiofrequency procedures for the treatment of symptomatic knee osteoarthritis: a systematic review. Pain Med. 2020;21(2): 333-48.

26. Urtis I, Jones M, Patel R i sur. Minimally invasive interventional management of osteoarthritic chronic knee pain. J Knee Surg. 2019;32(1):72-9.

27. Chen L, Duan X, Xing F i sur. Effects of pulsed electromagnetic field therapy on pain, stiffness and physical function in patients with knee osteoarthritis: a systematic review and meta-analysis of randomized controlled trials. J Rehabil Med. 2019;51(11): $821-7$.

28. Wu Y, Zhu S, Lv Z i sur. Effects of therapeutic ultrasound for knee osteoarthritis: a systematic review and meta-analysis. Clin Rehabil. 2019;33(12):1863-75.

29. Dantas LO, Carreira Moreira RF, Norde FM, Silva Serrao PRM, Alburquerque-Sendín F, Salvini TF. The effects of cryotherapy on pain and function in individuals with knee osteoarthritis: a systematic review of randomized controlled trials. Clin Rehabil. 2019;33(8):1310-9.

30. Radnovich R, Scott D, Patel AT i sur. Cryoneurolysis to treat the pain and symptoms of knee osteoarthritis: a multicenter, randomized, double-blind, sham-controlled trial. Osteoarthritis Cartilage. 2017;25(8):1247-56.

31. Wang Y-L, An C-M, Song S, Lei F-L, Wang Y. Cupping therapy for knee osteoarthritis: a synthesis of evidence. Complement Med Res. 2018;25(4):249-55.

32. Bernetti A, Mangone M, Alviti F i sur. Spa therapy and rehabilitation of musculoskeletal pathologies: a proposal for best practice in Italy. Int J Biometeorol. 2020;64:905-14.

33. Rodriguez-Merchan EC, De La Corte-Rodriguez H. The role of orthoses in knee osteoarthritis. Hosp Pract. 2019;47(1):1-5.

34. Grazio S. Međunarodna klasifikacija funkcioniranja, nesposobnosti i zdravlja (ICF) u najznačajnijim bolestima i stanjima reumatološke prakse. Reumatizam. 2011;58(1):27-43.

35. Kolasinski SL, Neogi T, Hochberg MC i sur. 2019 American College of Rheumatology/Arthritis Foundation guideline for the management of osteoarthritis of the hand, hip and knee. Arthritis Care Res (Hoboken). 2020;72(2):149-62.

36. Bannuru RR, Osani MC, Vaysbrot EE i sur. OARSI guidelines for non-surgical management of knee, hip and polyarticular osteoarthritis. Osteoarthritis Cartilage. 2019;27(11):1578-89. 